\title{
Effect of Pre-strain on Stress Corrosion Cracking of Type 304 Stainless Steel in High Temperature Water*
}

\author{
By Jiro KUNIYA,** Isao MASAOKA, ** Ryoichi SASAKI** \\ and Yusaku NAKAGAWA**
}

\section{Synopsis}

The effect of pre-strain on intergranular stress corrosion cracking (IGSCC) susceptibility of Type 304 stainless steel has been studied using a constant load tensile specimen in $288^{\circ} \mathrm{C}$ water containing $26 \mathrm{ppm}$ dissolved oxygen. The results obtained are summarized as follows:

(1) The time to failure of the specimens pre-strained at room temperature or $288^{\circ} \mathrm{C}$ are longer than those of non pre-strained specimens.

(2) The stress-strain behaviour of materials changes by pre-straining. The effect of pre-strain on IGSCC initiation could be explained in terms of a relation between the rupture of surface oxide film and the stress-strain behaviour of materials.

\section{Introduction}

The occurrence of Intergranular Stress Corrosion Cracking (IGSCG) of Type 304 stainless steel in oxygenated high temperature water has been known for several years. The key factors required for the occurrence of IGSGG of Type 304 stainless steel include the coincidence of three critical factors:

1) sensitization of material,

2) high tensile applied stress, and

3) corrosion environment. ${ }^{1)}$

The critical value of each factor depends on the degree of other factors. When high stress is working in heavy sensitized material, IGSGG may be initiated and propagate even in comparatively less aggressive environment such as the reactor water of BWR. The critical value of stress/strain for IGSGG initiation also varied from the degree of sensitization of material.

A number of studies including the effect of sensitization, ${ }^{2,3)}$ cold work, ${ }^{4-6)}$ surface grinding ${ }^{\text {1) }}$ and applied stress ${ }^{7)}$ on IGSGC of Type 304 stainless steel have been carried out over the past several years. The effect of deformation martensite on IGSCG has been also studied ${ }^{6,8)}$ related to the effect of cold work. As the results of the above studies, it has been demonstrated that Type 304 stainless steel becomes more susceptible to IGSGG by acceleration of degree of sen- sitization and high applied stresses over yield strength of material.

However, many studies have been carried out on the evaluation of metallurgical aspect under fixed applied stress condition so that the effect of stress/strain behaviour on IGSCG have not been clarified fully at this time.

Furthermore, the oxide film rupture theory has been proposed $^{9)}$ for mechanism of IGSCG initiation, but no initiation studies related to the oxide film rupture and stress-strain behaviour of materials have been carried out.

This study examines IGSCG susceptibility of Type 304 varying the stress-strain characteristic by prestraining to make clear the role of strain from the viewpoint of the oxide film rupture by plastic strain.

\section{Experimental Procedures}

Type 304 stainless steel was used in this experiment. The chemical compositions and mechanical properties of the material used are given in Table 1. The steel was received in the form of $9 \mathrm{~mm}$ plates. These plates were solution annealed at $1050^{\circ} \mathrm{C}$ for $50 \mathrm{~min}$.

Figure 1 shows the procedure of specimen preparation. After cutting the $9 \mathrm{~mm}$ plate, sensitization heat treatments at $621^{\circ} \mathrm{C}$ for $4 \mathrm{hr}$ or at $700{ }^{\circ} \mathrm{C}$ for $30 \mathrm{~min}$ plus at $500{ }^{\circ} \mathrm{C}$ for $24 \mathrm{hr}$ were given, and then the specimens for pre-straining were machined with emery paper \#04 finishing as shown in Fig. 2.

The uniaxial constant load specimens for the evaluation of IGSCG susceptibility shown as dotted line in Fig. 2 were cut from the pre-strained material with an intact surface. The amount of pre-strain is calculated from the following equation.

$$
\varepsilon=\frac{l-l_{0}}{l_{0}} \times 100(\%)
$$

where, $l_{0}:$ initial gauge length $(50 \mathrm{~mm})$

$l$ : gauge length after pre-straining $(\mathrm{mm})$.

Table 1. Chemical composition (wt \%) and mechanical properties of alloy.

\begin{tabular}{c|ccccccccc}
\hline Alloy & $\mathrm{G}$ & $\mathrm{Si}$ & $\mathrm{Mn}$ & $\mathrm{P}$ & $\mathrm{S}$ & $\mathrm{Ni}$ & $\mathrm{Cr}$ & $\mathrm{Co}$ & $\mathrm{B}$ \\
\hline 304 & 0.06 & 0.52 & 1.21 & 0.032 & 0.006 & 8.62 & 18.17 & 0.21 & 0.0001 \\
\hline \hline & & $\begin{array}{c}\text { Tensile strength } \\
\left(\mathrm{kg} / \mathrm{mm}^{2}\right)\end{array}$ & $\begin{array}{c}0.2 \% \text { offset yield } \\
\text { strength }\left(\mathrm{kg} / \mathrm{mm}^{2}\right)\end{array}$ & $\begin{array}{c}\text { Elongation } \\
(\%)\end{array}$ & $\begin{array}{c}\text { Reduction of area } \\
(\%)\end{array}$ & $\begin{array}{c}\text { ASTM grain } \\
\text { size }\end{array}$ \\
\hline Room temp. & 74.4 & & 23.8 & 79.0 & 81.5 & 5.5 \\
$288^{\circ} \mathrm{C}$ & 46.2 & & 17.7 & 45.4 & 71.3 & - \\
\hline
\end{tabular}

* Originally published in Boshoku Gijutsu (Corrosion Engineering), 29 (1980), 397, in Japanese. English version received February 16, 1981.

** Hitachi Research Laboratory, Hitachi Ltd., Saiwai-cho, Hitachi 317. 
The specimens were pre-strained at room temperature or $288{ }^{\circ} \mathrm{C}$. In the case of the specimens prestrained at room temperature, the martensite will be induced by plastic deformation, and IGSCG initiation could be affected by the deformation martensite. Therefore, the pre-straining was also given at $288^{\circ} \mathrm{C}$ which is far above $\mathrm{Md}$ point, the maximum temperature for martensite formation by deformation. The specimens pre-strained at room temperature were heat treated at $621^{\circ} \mathrm{C}$ for $4 \mathrm{hr}$ and the specimens pre-strained at $288^{\circ} \mathrm{C}$ were heat treated at $700{ }^{\circ} \mathrm{C}$ for $30 \mathrm{~min}$ plus at $500^{\circ} \mathrm{C}$ for $24 \mathrm{hr}$.

The stress-strain curve at $288^{\circ} \mathrm{C}$, the amount of deformation martensite, and the surface roughness of the specimens pre-strained at either room temperature or $288^{\circ} \mathrm{C}$ were measured.

The uniaxial constant load specimens as shown in Fig. 2 were used for IGSCG test in high temperature oxygenated water. The facility is capable of testing 150 uniaxial constant load specimens in the test vessel at a constant load. The specimens were loaded through a piston with a test pressure of $85 \mathrm{~kg} / \mathrm{cm}^{2}$ as shown in Fig. 3.11) The applied stress levels on the specimens were established by varying the cross section of the specimens at a constant load of $424 \mathrm{~kg}$. In this experiment, the applied stress level was fixed at $30 \mathrm{~kg} / \mathrm{mm}^{2}$.

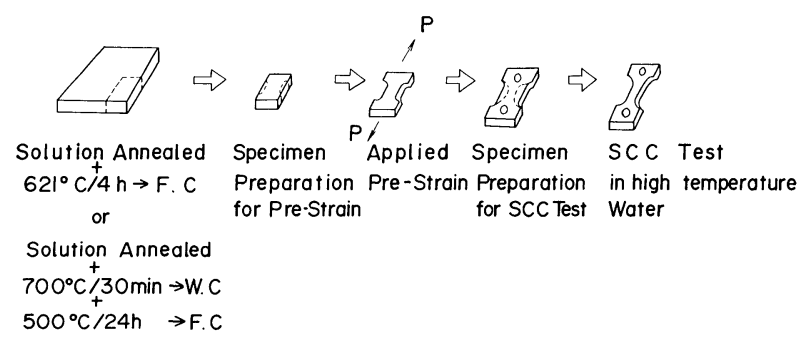

Fig. 1. Specimen preparation procedure.
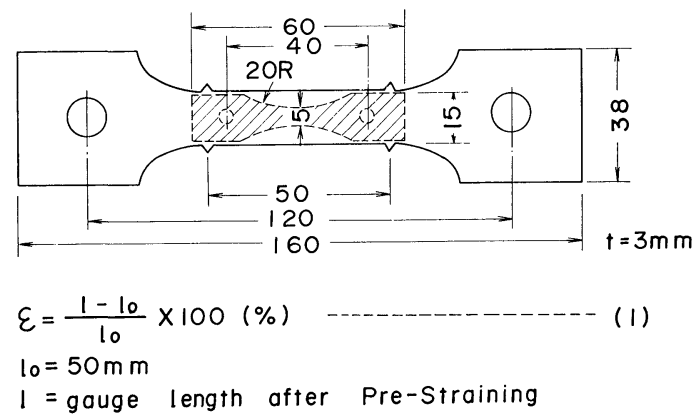

Fig. 2. Specimen configuration.

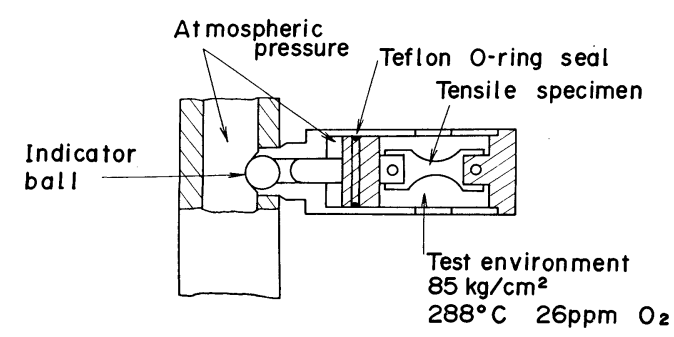

Fig. 3. Detail of uniaxial tensile specimen loading device.
Upon failure of a specimen, a numbered stainless steel ball indicating the identity of the failed specimen was ejected from the specimen holder and dropped down the manifold and out of the test vessel. The time to failure was indicated by a small fluctuation on the recorder caused by a limit switch when the indicator ball went through it.

The environmental conditions are as follows;

Testing temperature: $288^{\circ} \mathrm{C}$

Dissolved oxygen : about $26 \mathrm{ppm}$

Conductivity $:<1 \mu \mathrm{mho} / \mathrm{cm}$

Flow rate $\quad: 100 l / \mathrm{h}$

\section{Results}

\section{IGSCC Test Results}

Figure 4 shows IGSGG test results. It is shown from Fig. 4 that the time to failure of the specimens pre-strained at room temperature or $288{ }^{\circ} \mathrm{C}$ is longer than those of the non pre-strained specimens. The specimens pre-strained by 16 and $20 \%$ are still under testing over $7000 \mathrm{hr}$. As shown above, the initiation of IGSCG of Type 304 is retarded by pre-straining.

\section{Stress-Strain Characteristic of Pre-strained Specimens}

Stress-strain curve of the pre-strained specimens at $288^{\circ} \mathrm{C}$ are given in Fig. 5. In this experiment, the applied stress was fixed at $30 \mathrm{~kg} / \mathrm{mm}^{2}$ so that the amount of strain corresponding to the applied stress of $30 \mathrm{~kg} / \mathrm{mm}^{2}$ can be presented as shown in Fig. 6 based on the results shown in Fig. 5. The amount of strain corresponding to the applied stress of $30 \mathrm{~kg} /$ $\mathrm{mm}^{2}$ at $288{ }^{\circ} \mathrm{C}$ decreases with increasing the amount of pre-strain, and it becomes less than about $0.2 \%$ above $8 \%$ pre-strain.

Figure 7 shows the relation between the amount of pre-strain and the mechanical properties of the material at $288{ }^{\circ} \mathrm{C}$. $0.2 \%$ off-set yield strength, $\sigma_{y}$ and tensile strength, $\sigma_{u}$ increase and reduction of area decreases with increasing the amount of pre-strain.

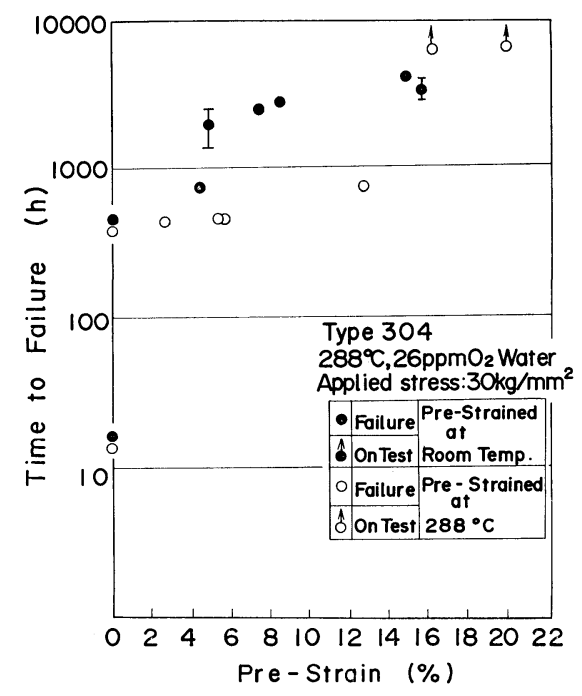

Fig. 4. Effect of pre-strain on time to failure of Type 304 stainless steel specimens in high temperature water. 
The yield strength, $\sigma_{y}$ and reduction of area of the specimens pre-strained at room temperature or $288^{\circ} \mathrm{G}$ are almost the same, but the tensile strength, $\sigma_{u}$ of the specimens pre-strained at room temperature becomes greater than those pre-strained at $288{ }^{\circ} \mathrm{C}$ above $10 \%$ pre-strain.

\section{Deformation Martensite and Surface Roughness of the Pre-strained Specimens}

Figure 8 shows the relation between the amount of

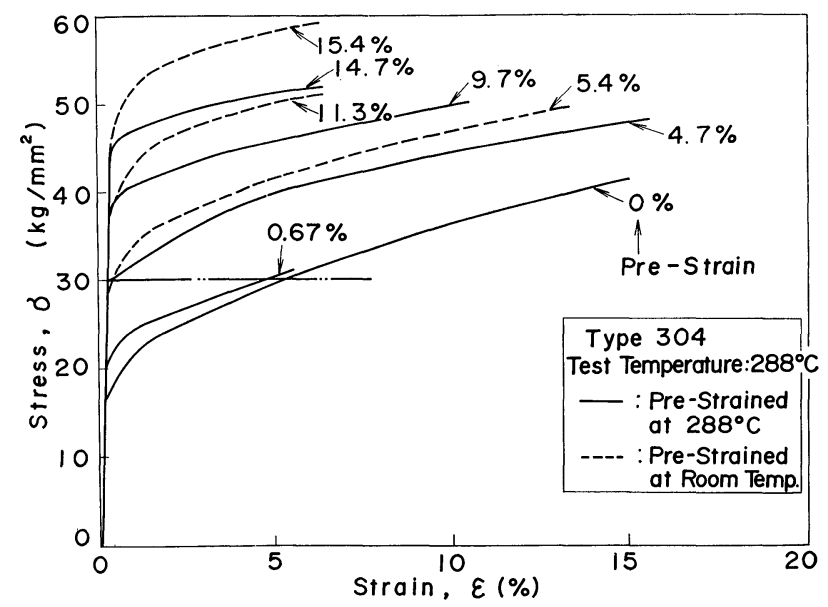

Fig. 5. Stress-strain curve of pre-strained material.

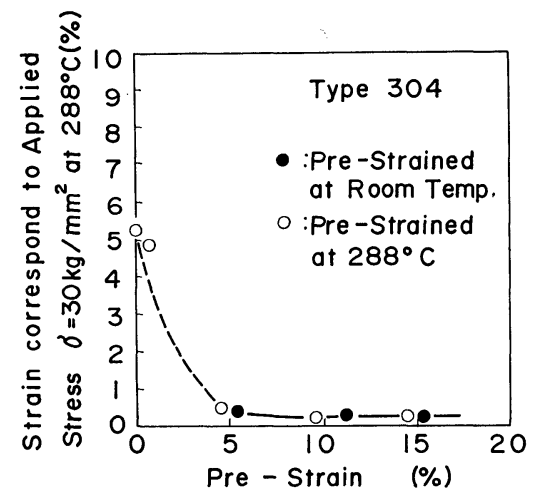

Fig. 6. Relation between pre-strain and strain corresponding to applied stress, $\sigma=30 \mathrm{~kg} / \mathrm{mm}^{2}(294.2 \mathrm{MPa})$ at $288^{\circ} \mathrm{C}$.

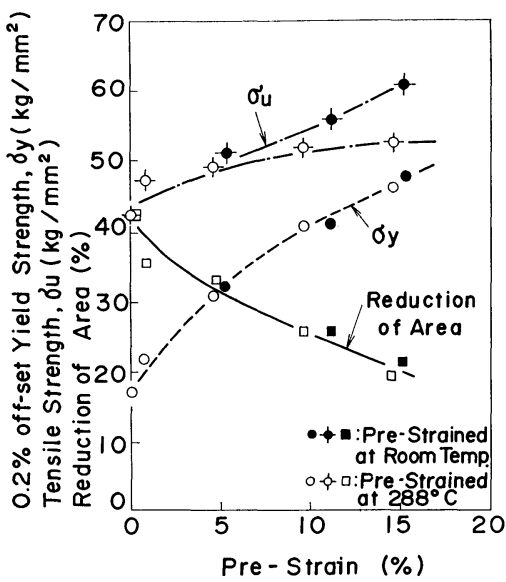

Fig. 7. Effect of pre-strain on mechanical properties at $288^{\circ} \mathrm{C}$. (Type 304 ) deformation martensite and of pre-strain. In the case of the specimens pre-strained at room temperature, the amount of deformation martensite increases with increasing the pre-strain as shown in Fig. 8. On the other hand, the amount of martensite of the specimens pre-strained at $288{ }^{\circ} \mathrm{C}$ is about $25 \%$ regardless the amount of pre-strain. It is estimated that the $\mathrm{Md}$ point of the material used in this experiment based on Angel's equation ${ }^{12}$ ) is about $40^{\circ} \mathrm{C}$. It is considered, therefore, that the phase transformation will not occur at $288^{\circ} \mathrm{C}$ even if the specimens are prestrained. Then, the amount of deformation martensite of the specimen was re-examined after electropolishing which removed the surface layer introduced by emery paper finishing. After electropolishing, no martensite was observed in the specimen pre-strained at $288{ }^{\circ} \mathrm{C}$. It is indicated that the observed deformation martensite of about $25 \%$ was caused by emery paper \#04 finishing at room temperature.

Figure 9 shows the relation between the maximum surface roughness and the amount of pre-strain. The maximum surface roughness of the pre-strained specimens became greater than that of non pre-strained specimens, but there is no significant changes of the maximum surface roughness above $5 \%$ pre-strain.

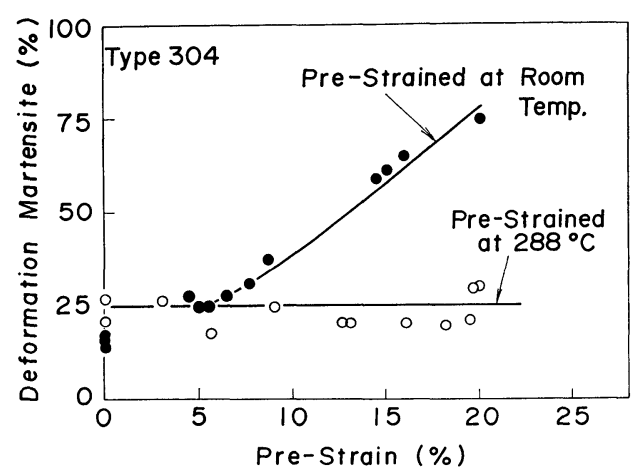

Fig. 8. Relation between pre-strain and the amount of deformation martensite.

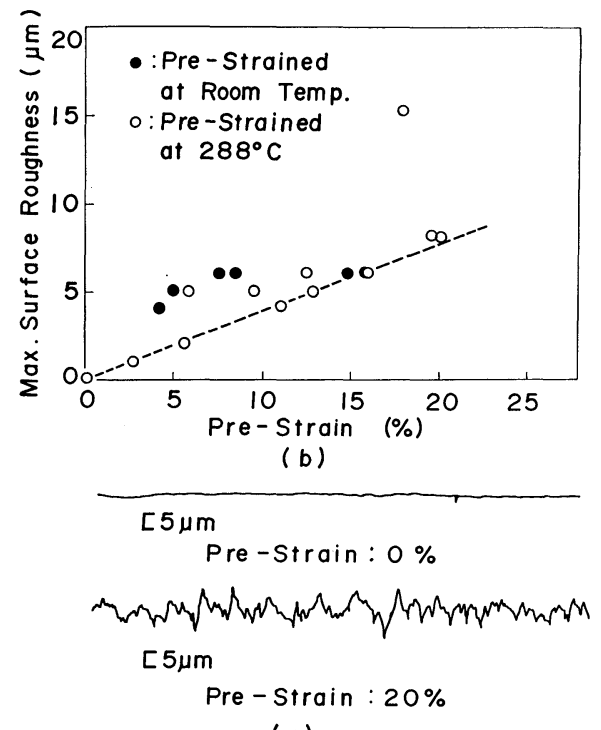

(a)

Fig. 9. Effect of pre-strain on the maximum surface roughness. 
The maximum surface roughness of the specimen prestrained by $20 \%$ is less than $10 \mu \mathrm{m}$ at most.

\section{Discussion}

It has demonstrated from IGSGG test results shown in Fig. 4 that the initiation of IGSCG of Type 304 is retarded by pre-straining. The effect of prestrain on IGSGG will be discussed here taking into consideration that the stress-strain behaviour, the change of surface roughness and the change of deformation martensite by pre-straining.

Figure 10 shows the relation between the strain corresponding to the applied stress, $\sigma=30 \mathrm{~kg} / \mathrm{mm}^{2}$ at $288^{\circ} \mathrm{C}$ and the time to failure from the results shown in Fig. 6. It is shown that the initiation of IGSCC is retarded when the strain is less than about $0.2 \%$ (the range of elastic deformation). Rupture of the surface oxide film of the pre-strained specimens could be retarded when the deformation of specimens is within elastic range.

Figure 11(a) shows the SEM observations of the specimens loaded at $30 \mathrm{~kg} / \mathrm{mm}^{2}$ and $14 \mathrm{~kg} / \mathrm{mm}^{2}$, respectively. In the case of the specimen loaded at $30 \mathrm{~kg} / \mathrm{mm}^{2}(\varepsilon=4.8 \%)$, intergranular cracking is observed. On the other hand, there are no cracks in the specimen loaded at $14 \mathrm{~kg} / \mathrm{mm}^{2}(\varepsilon=0.5 \%)$. Fig- ure 11(b) shows the SEM observations of the specimen loaded after pre-straining of $23 \%$. The specimen pre-strained by $23 \%$ extend elastically even if the stress is applied up to $30 \mathrm{~kg} / \mathrm{mm}^{2}$, and the amount

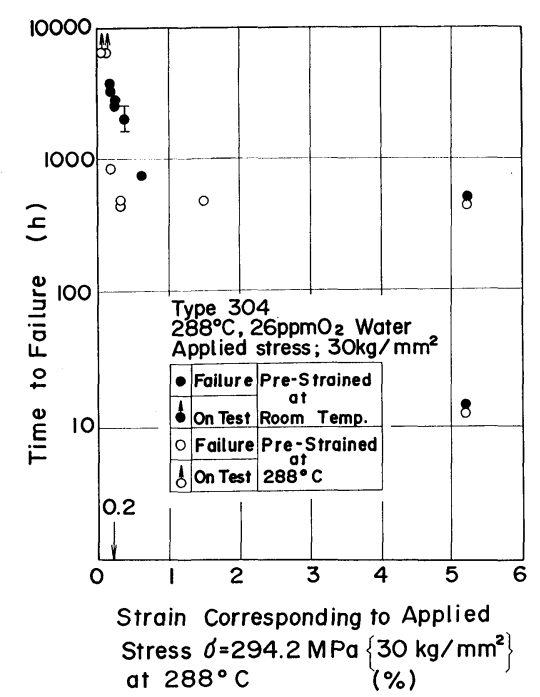

Fig. 10. Relation between time to failure and strain corresponding to applied stress, $\sigma=30 \mathrm{~kg} / \mathrm{mm}^{2}$ at $288^{\circ} \mathrm{C}$.
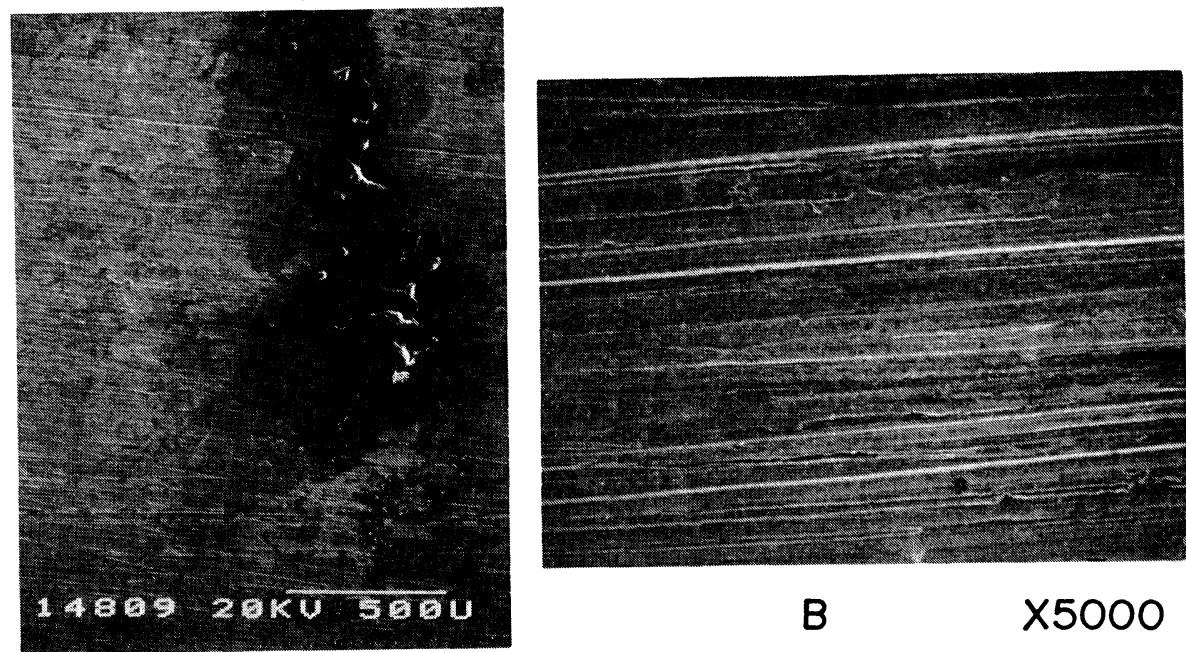

B

$\times 5000$

Fig. 11(a).

SEM observations of specimen surface after unloading. $(\times 7 / 10)$
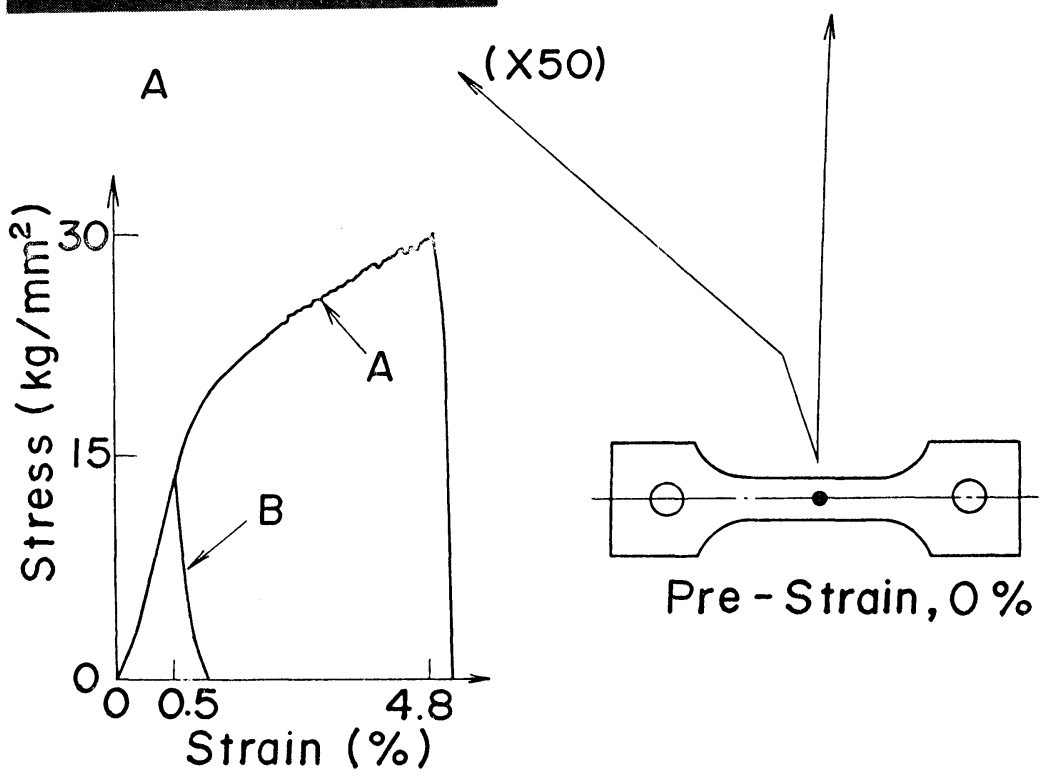

Pre - Strain, $0 \%$ 
of strain corresponding to $30 \mathrm{~kg} / \mathrm{mm}^{2}$ is about $0.45 \%$. In this case, IGSGG initiation was not observed as shown in Fig. 11(b). From the above SEM observations, it is supported that the rupture of surface oxide film will be suppressed when the amount of strain is within elastic deformation range.

Figure 12 shows the relation between the applied stresses and the time to failure of Type 304 sensitized heavily. As a result, 2 of 3 specimens loaded below nominal $0.2 \%$ off-set yield strength, $\sigma_{y}$ at $288{ }^{\circ} \mathrm{C}$ are still on test without failure even if they are sensitized heavily. But the specimen heat treated at $700{ }^{\circ} \mathrm{G}$ for $30 \mathrm{~min}$ plus at $500^{\circ} \mathrm{C}$ for $24 \mathrm{hr}$ failed after about $6000 \mathrm{hr}$ even if it was loaded below nominal $0.2 \%$ off-set yield strength, $\sigma_{y}$. As above indicated, IGSGG of Type 304 stainless steel can occur under the applied stress level of below nominal $0.2 \%$ off-set yield strength, $\sigma_{y}$ when the material is sensitized severely by heat treatment such as at $700{ }^{\circ} \mathrm{C}$ for $30 \mathrm{~min}$ plus at $500{ }^{\circ} \mathrm{C}$ for $24 \mathrm{hr}$. It is indicated that the critical value of stress/strain factor may vary with the degree of sensitization of material as mentioned earlier in this paper.

Next, the effect of the deformation martensite and the surface roughness on IGSCG will be discussed. From Fig. 8, the amount of deformation martensite of the specimens pre-strained at room temperature are larger than those of the specimens pre-strained at $288^{\circ} \mathrm{C}$. In the case of the specimens pre-strained by 6 to $14 \%$, the time to failure of the specimens pre-strained at room temperature seems to be longer than those of the specimens pre-strained at $288{ }^{\circ} \mathrm{C}$ as shown in Fig. 4. The reasons for the above phenomena do not clear at this time, however, it could be thought that the deformation of specimen such as micro-creep is controlled by the deformation martensite and then IGSGG is controlled. Much more work is needed, however, to develop the quantitative inter-

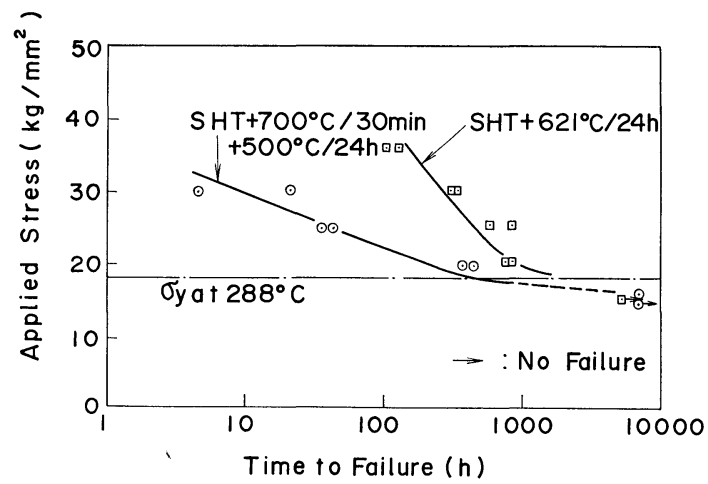

Fig. 12. Effect of applied stress on time to failure. (Type $304, \mathrm{C}=0.06 \%, 288^{\circ} \mathrm{C}, 26 \mathrm{ppm} \mathrm{O}_{2}$ water)
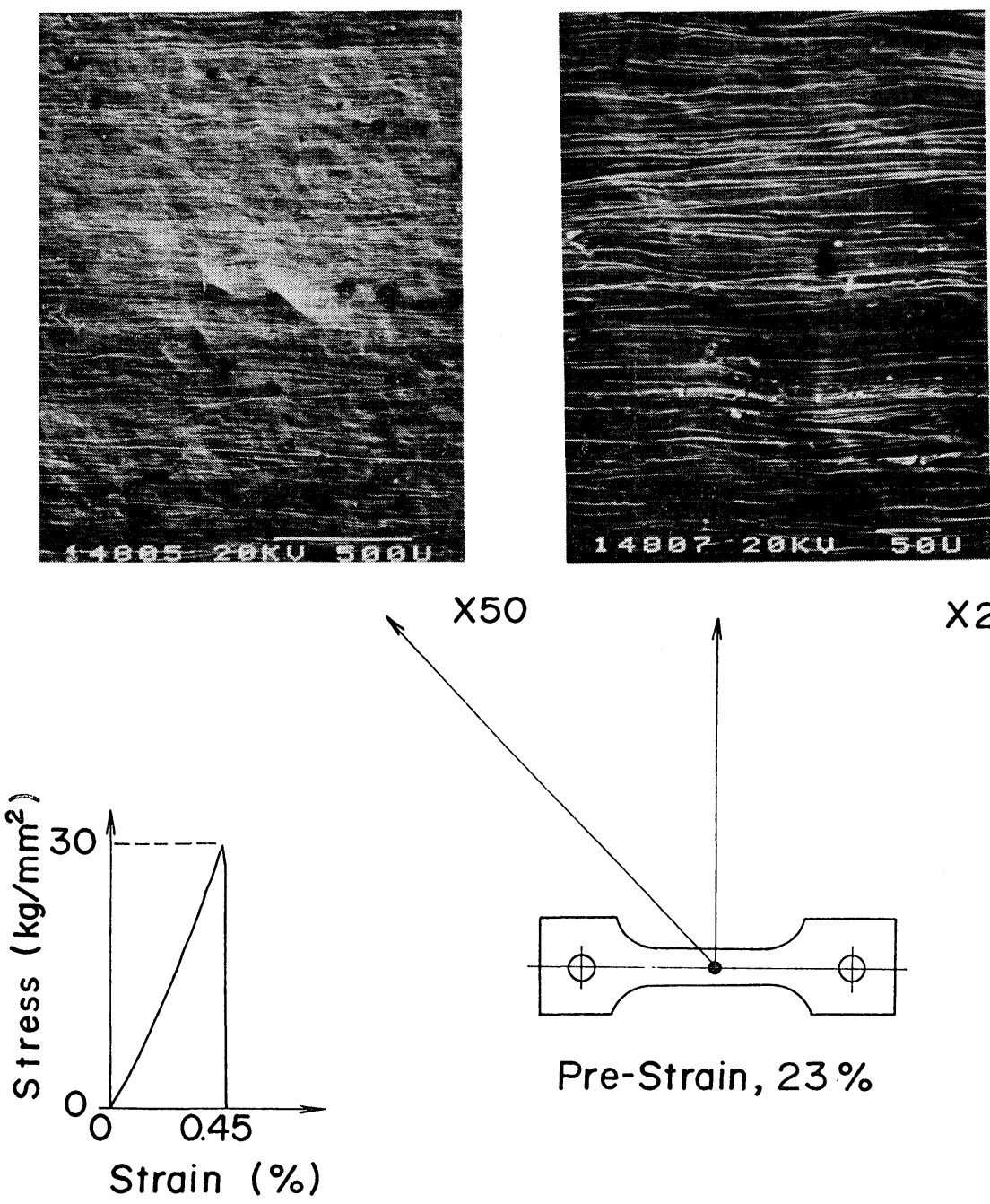

Pre-Strain, $23 \%$
Fig. 11(b).

SEM observations of pre-strained specimen surface after unloading. $(\times 2 / 3)$ 
play between the deformation martensite and IGSCG susceptibility.

The surface roughness of the specimens pre-strained over $5 \%$ fall about 5 to $8 \mu \mathrm{m}$ at most as shown in Fig. 9. The surface roughness of the non pre-strained specimens also becomes about $5 \mu \mathrm{m}$ after loading in uniaxial constant load test. Therefore, in this experiment, the surface roughness of the non pre-strained specimens is almost the same order as that of the specimens pre-strained during uniaxial constant load test. It could be thought that there is no significant effect of surface roughness on IGSCG test results.

From the above discussion, it could be concluded that the strain caused in the materials is a primary factor for IGSGG initiation of Type 304.

\section{Conclusions}

Conclusions drawn from this study are as follows:

(1) The time to failure of the specimens prestrained at room temperature or $288^{\circ} \mathrm{C}$ become more longer than those of the non pre-strained specimens in IGSGC test. IGSCG initiation is retarded by pre-straining.

(2) The changes of stress-strain characteristic of the materials due to pre-straining is a primary factor for IGSCG initiation of Type 304. Since the rupture of the surface oxide film is retarded when the deformation of the materials is within an elastic range, the initiation of IGSCG is retarded.

\section{Acknowledgements}

The authors are indebted to Messrs. M. Miki and H. Ito of Hitachi Works, Hitachi Ltd., for their helpful discussion. The SGC testing by Mr. M. Kanno of Hitachi Research Lab., Hitachi Ltd., is also gratefully acknowledged.

\section{REFERENGES}

1) W. L. Clarke and G. M. Gordon: Corrosion, 29 (1973), 1.

2) M. J. Povich and P. Rao: Corrosion, 34 (1978), 269.

3) M. Hishida and H. Nakada: Corrosion, 34 (1978), 338.

4) C. S. Tedmon, D. A. Vermilyea and D. E. Broecker: Corrosion, 27 (1971), 104.

5) M. Chikazaki and K. Soeno: Tetsu-to-Hagané, 64 (1978), 1363.

6) M. Kowaka, H. Nagano and T. Kudo: Boshoku Gijutsu (Corrosion Engineering), 28 (1979), 631.

7) J. Kuniya, I. Masaoka, R. Sasaki, Y. Nakagawa and A. Naruse: Boshoku Gijutsu (Corrosion Engineering), 27 (1978), 393.

8) H. Uchida, K. Oterazawa and I. Yamada: Boshoku Gijutsu (Corrosion Engineering), 25 (1976), 543.

9) D. A. Vermilyea: J. Electrochem. Soc., 119 (1972), 405.

10) A. Kitada and T. Nakayama: J. Japan Inst. Metals, 38 (1974), 37.

11) A. E. Pickett and R. G. Sim: Mat. Protect. Perform., 12 (1973), 39.

12) T. Angel: JISI, 177 (1954), 165. 